This is an electronic reprint of the original article. This reprint may differ from the original in pagination and typographic detail.

Author(s): Perez-Estebanez, Raquel; Urquía-Grande, Elena; Rautiainen, Antti

Title: $\quad$ Technological and Economic Factors Determining ICT Level : Evidence from Rural Micro-Businesses in Democratic Republic of Congo

Year: $\quad 2018$

Version:

Please cite the original version:

Perez-Estebanez, R., Urquía-Grande, E., \& Rautiainen, A. (2018). Technological and Economic Factors Determining ICT Level : Evidence from Rural Micro-Businesses in Democratic Republic of Congo. Journal of International Development, 30(1), 118-133. https://doi.org/10.1002/jid.3281

All material supplied via JYX is protected by copyright and other intellectual property rights, and duplication or sale of all or part of any of the repository collections is not permitted, except that material may be duplicated by you for your research use or educational purposes in electronic or print form. You must obtain permission for any other use. Electronic or print copies may not be offered, whether for sale or otherwise to anyone who is not an authorised user. 


\title{
Technological and Economic factors determining ICT level: \\ Evidence from rural micro-businesses in Democratic Republic of Congo
}

Version 15.03.2017

Raquel Perez-Estebanez (Universidad Complutense de Madrid, UCM)

Elena Urquia-Grande (UCM)

\& Antti Rautiainen (University of Jyväskylä)

\begin{abstract}
The Democratic Republic of Congo (DRC) is the eleventh largest country in the world although wars have devastated the economics of the country. In this vast but poor area, there are a lot of small businesses, particularly in agriculture. Therefore focusing on small enterprises and their use of Information and Communication Technologies (ICT) can be a key issue in enhancing the nation's infrastructure, communications, social relations and economy. This research aims at increasing our understanding of these issues together by analysing the effects of ICT in micro-level businesses in a developing country. The research focused on the rural neighbourhood of Ngandanjike in the area of Mbujimayi in south DRC. Two hundred agricultural micro-entrepreneurs were randomly surveyed by a Non-Profit Organisation (NPO) about their current situation regarding their ICT use, ICT access, mobile phone use, ICT education level and accounting information systems. Multivariate statistics models were used in the data analysis. After analysing the regression of the six ICT factors and additional financial data as total revenues and total assets, we found micro-entrepreneurial total assets are connected with management accounting with ICT, ICT education level and ICT adoption. We contribute to existing research by adding empirical evidence, at a microeconomic level of agricultural micro-enterprises, on the effects of ICT access and use as an engine of local economic growth. Additionally this research can impact policy decisions regarding microentrepreneurs, seeking to reduce poverty by understanding what ICT factors are most valued and most needed by these micro-entrepreneurs to help them with sustainable economic activity and to alleviate the poverty. Policy makers need to emphasize training and motivation for micro-entrepreneurs in order to deepen their ICT knowledge and to help their business.
\end{abstract}

Keywords: Information and Communication Technologies; Accounting and Tax Management, Democratic Republic of Congo, Agriculture. 


\section{Introduction}

Information and Communication Technologies (ICT) are expected to automatize processes and facilitate effectiveness and thus help to reduce poverty in developing countries, though many development projects in developing countries tend to remain at the level of good intentions only (Karlan and Appel, 2011; Karlan and Valdivia, 2010; Mason, 2014). However, both microfirm level entrepreneurial work and ICT or other training may have potential in reducing poverty (see e.g. Bing and Epstein, 2013; Karlan and Valdivia, 2010). This research aims at increasing our understanding of these issues taken together by analysing the effects of ICT on micro-level businesses in a developing country. The research focused on one of the poorest areas of Kinshasa (the capital of DRC), where the average household lives on less than \$US 2.00 per day. Two hundred agricultural micro-entrepreneurs were randomly surveyed by NonProfit Organisations (NPOs) volunteers about their current situation regarding their ICT use, ICT access, mobile phone use, ICT education level and accounting information systems and tax planning in line with Karlan and Valdivia (2010) and Mason (2014).

Focusing on micro-enterprises can be the key to boosting DRC's emerging economy but little is known about these firms, their management, financial resources or about the effect of adopting ICT on micro-enterprises. Small enterprises and ICT can in fact be the key tools to enhance productivity, infrastructure, communications and social relations. There has been relatively little research, however, on how different ICT tools can support new business projects in different sectors (economic, health or social) in Africa and Asia (Chowdhury, 2003; Heeks, 2010; Ojo, Janowski and Awotwi, 2013; Mansell, 2014; Mengiste and Aanestad, 2013). Rich natural resources and their effective use, assisted by ICT, could open attractive opportunities for growth of the economy and communication, such as broadband adaptation, but these would require strategic and stable governmental policies and investments (see also Armenta et al., 2012). The potential of ICT is constrained by limited access to infrastructure and by the lack of formal education and training as well as by financial constraints and political conflicts (Pade, Mallinson and Sewry, 2008).

By adding empirical evidence of agricultural micro-enterprises at a microeconomic level, we contribute to existing research on the effects of ICT access and use as an engine of economic growth (e.g. Bollou and Ngwenyama, 2008; Oliveira and Fraga, 2011). Our results indicate that the ICT use of agricultural micro-enterprises is related to the level of assets (in line with Bollou and Ngwenyama, 2008), and that the use of mobile phones in micro-business context can facilitate economic growth (in line with Wade, 2004; Mbarika, 2002; and Heeks and Arun, 2010 and Donner, 2006). Interestingly, we also note the difficulties (e.g. due to translation and interpretation of survey questions) in conducting international development research in Africa. Finally we note that even though ICT research has long considered the factors determining ICT use in developing countries, research on these issues is still scarce in African contexts (see Walsham and Sahay, 2006). Additionally the findings of this study have implications for public policy regarding the development of micro-enterprises, poor households, governments and NPOs seeking to reduce poverty in cities. Understanding what ICT tools are needed and most valued by these micro-entrepreneurs will help micro-entrepreneurs to be sustainable and will alleviate their poverty (in line with Quereshi, 2006). Policy makers need to emphasize training and motivation for micro-entrepreneurs in order to deepen their ICT knowledge and to help 
their business. Moreover, ICT use, such as mobile communication, can speed up processes and cut costs so dramatically that new ways of company management could become possible. The digitalization of data is part of it, allowing resource management and communication of information at virtually zero cost. The increasingly connectivity of ICT allows new relations and network structures to exist. Tools for a digital economy are progressively in the hands of the worlds' poor (Heeks, 2010), and there are studies that support the theory that the proper adoption and use of information technologies increases the productivity of the company and can be a decisive influence on the wealth and growth of a country (Dozier and Chang, 2006). According to the OECD, countries with greater investment in these technologies are also leading the growth rates of productivity (OECD, 2015).

This research takes into account the problems with ICT access and use, and in particular the ICT adoption difficulties faced by the sub-Saharan African countries (see also Ewushi-Mensah, 2012). Factors such as power failure, telecommunications infrastructure and types of computer hardware and software might be taken into consideration in order to measure the certainty of using ICT with the aid of a stable supply of electrical power, which is a major problem in most sub-Saharan countries and specifically in the DRC. The effect of power failures, however, was not taken into account, only appearing when discussed with the microentrepreneurs. Future research lines could be to improve the survey so it includes more items focused on specific problems of ICT diffusion (following Ewushi-Mensah, 2012).

This paper is structured in the following way. First, the context of the DRC is described with a brief bibliographic review of studies of ICT and micro-entrepreneurship in developing countries. Then the data collection phase and the micro-entrepreneurs sample are described. Multivariate statistics models were used in the data analysis. Findings are presented and, finally, the implications of the research are discussed. We found, using principal components analysis, several ways of using ICT (such as using only mobile technology). After analysing the correlation of the components and some financial data, we also found that ICT and microentrepreneurial success are connected and reinforce each other in finding a way out of poverty in the DRC context.

\section{The context of the Congo}

The Democratic Republic of Congo (DRC) is the second largest country in Africa by area and the eleventh largest in the world with a population of over 75 million. The DRC is the nineteenth most populous nation in the world although the wars and civil wars beginning in 1998 (at the latest), devastated the country. In particular, the so-called Second Congo War has been the world's deadliest conflict since 1998, although more than $90 \%$ of the over 5 million casualties were not killed in enemy combat, but by malaria, diarrhoea, pneumonia and malnutrition, factors all aggravated by displaced populations living in unsanitary and over-crowded camps or in other conditions that lacked access to shelter, water, food and medicine. The DRC is, however, one of the richest countries in the world in natural resources. Although DRC has $70 \%$ of the world's coltan (a mineral used for mobile phone manufacturing), a third of cobalt, more than $30 \%$ of diamond reserves and a tenth of copper, the economy continues to decline drastically (Exenberger and Hartmann, 2007). The control of the mineral wealth is, obviously, a key reason behind the conflicts and especially behind some of the most violent activities. 
These on-going conflicts exacerbate the exhaustion of the country's great agricultural and mineral potential. Despite the huge natural resource potential of the country, the Congolese people consistently have one of the lowest nominal GDPs per capita and Human Development Index (HDI) ratings in the world (World Bank, 2015) (see Table 1).

Table 1

\section{ICT and the development context}

In the case of Africa many studies have shown that achieving long-term social and economic development requires an enabling environment which relies on, among other factors, free communication and ICT (Dasuki, Abbott and Azrikatoa, 2014; Ghaus-Pasha, 2007; Hilty and Ruddy, 2010; Mbaku, 2000; Ojo et al., 2013). The causality between ICT and technological efficiency has been demonstrated in both developed countries (Brynjolfsson and Hitt, 1998; Solow, 1957) and in developing countries (Bollou and Ngwenyama, 2008). ICT may enhance productivity, can serve to transform and modernise organizational culture, and holds great potential for development, industrialization and economic growth (Tongia, Subrahmanian and Arunachalam, 2004; Kayisire and Wei, 2016). In order to understand the potential impact of ICT on development, several implementation scenarios have been produced (Orliwoski and Iacono, 2001; Sein, 2004). A research trend has been to take the micro-enterprise as the unit of analysis, and has sought to understand the contribution of ICT to development through ICT impact on micro-, small- and medium-sized enterprises. For example, Heeks and Molla (2009) use a variety of business-management frameworks to analyse enterprise variables. Further, Kayisire and Wei, 2016, have studied and demonstrated the relative efficiency of ICT adoption and usage in 6 African countries with DEA analysis. Esselaar, Stork and Ndiwalana (2006) found that ICT adoption is linked to higher labour productivity and higher sales turnover in African SMEs, regarding them as success variables for development to be achieved. Orlikowski and lacono (2001) identify the classic diffusion of innovations approach developed by Rogers (2003) as another possible theme in technology research.

The rapid advance in technology has opened up the possibility of generating and using information from a strategic standpoint. While this is important for all companies, medium and small size companies need this information to deal with a greater degree of uncertainty in the competitive market (EI Louadi, 1998). Authors like Cooper and Burgess (2000) and Maswera, Dawson and Edwards (2008) highlight the importance of implementing ICT in small companies to overcome the disadvantages of firm size, limited financial, technological and human resources, and limited exposure to the global market. The main advantages of optimal utilization of ICT in SMEs include better adaptation to a changing environment, better management of long distance relationships and a higher degree of competitiveness.

The diffusion of ICT into low-income countries and communities has been recent and rapid. ICT use, together with human and financial capital, can contribute to development in several ways. Firstly, ICT tools can aid development and economic growth by saving money, which is essential for entrepreneurs from low-income communities (Abraham, 2007; Donner and 
Escobari, 2010; Levy, Chew and Ilavarasan, 2010, Loh, 2013). Nevertheless, cost-benefit type analyses (see Jensen, 2007) are scarce, especially in the relatively unstable DRC context, which may affect the risks and returns on investment at both individual and community microenterprise levels. Secondly, accounting and financial software packages can enable sustainability development because ICTs enable new financial strategies that produce improved environmental outcomes in the long term (e.g. using less paper, see also Heeks and Arun, 2010; Molla and Al-Jaghoub, 2007). ICTs can facilitate development through virtual education (Kivunike et al., 2009; Olatokun, 2009) where ICT training increases the capabilities and motivation among employees and also among the unemployed people in the villages, factors which may facilitate better hygiene, better crops and new micro-enterprises. However, there is relatively little empirical evidence about ICT contribution to development in Africa. Thus more evidence is needed; especially from a microeconomic point of view. Factors such as power reliability should be taken into account and contextualized in the sub-Saharan countries as factors which limit ICT use and constrain the positive impact of ICT in the micro-companies (Ewushi-Mensah, 2012).

Regarding ICT used for business in Africa, micro firm level studies (Adeoti \& Adeoti, 2008) have examined the appeal of the mobile phones in Nigeria using mobile phone adoption at the enterprise level as the dependent variable. Further, instead of focusing on individual needs and behaviors, some econometric studies have compared mobile penetration within or across nations: some seek to describe penetration rates using geography and income (BaliamouneLutz, 2003), income alone (Rouvinen, 2006), the quality of the institutional environment (Andonova, 2006), or socio-cultural attributes and Internet/telecom use (Kamssu, 2005). Some fit existing diffusion models to developing-world contexts (Kumar et al., 2007; Varadharajan, 2007; Koski \& Kretschmer, 2007). Others (Banerjee \& Ros, 2004; Dholakia et al., 2004) identify distinct patterns of mobile utilization instead of trying to fit all nations to a single model. James and Versteeg (2007) raise an interesting caution that might apply to all studies, pointing to unreliable measures of mobile penetration and use in Africa, given the poor industry data and pervasive prepaid and shared use. Adding to this list, in this paper, we found difficulties of translation leading to unreliable measurements. Other researches in DRC SMEs demonstrate that a majority reported a cell phone number, making this tool the most popular, some reported an e-mail address, and a minority reported a firm web site (Kabongo \& Okpara, 2014). Some researchers have argued that the mobile phone is a more accessible, less expensive means to "close" this global divide (Wade, 2004; Mbarika, 2002; Kenny, 2002; Snowden, 2000). Others use the "digital divide" to distinguish between mobile phone users and non-users, or between telephone users and non-users. Used in this way, the digital divide is a new reference to the existing inequities historically addressed by universal service and universal access initiatives. The rationale for impact studies is clear: the mobile is a powerful tool for exchanging ideas at a distance, and for managing daily life.

The clearest examples of impact studies come from the ICT for development perspective where researchers are interested in whether mobiles promote economic growth or broader well-being (Sridhar \& Sridhar, 2006). These studies echo earlier work on telecommunications and economic development (Norton, 1992; Hardy, 1980; Saunders, Warford, \& Wellenieus, 1994). Thompson and Garbacz (2007) used a stochastic model to identify a positive effect of telecommunications (particularly mobiles) on productive efficiency in developing nations. 
Waverman, Meschi, and Fuss (2005) also take the macro view, reporting that higher levels of mobile penetration lead to higher rates of gross domestic product (GDP) growth, particularly among low-income developing countries. Williams, 2005; Lydon \& Williams, 2005 found a correlation between mobile penetration levels and inflows of foreign direct investment. A microeconomic study used a survey approach to explore how mobiles contribute to increase social capital (cohesiveness) within communities in South Africa and Tanzania (Goodman 2005). Another microeconomic study focused on how people use mobiles to start and open businesses, and to keep in touch with friends and family (Samuel, Shah, \& Hadingham, 2005). There is a strong intermingling of business (instrumental) and personal uses of the mobile, however, among small business owners (Donner, 2010). A survey of urban microentrepreneurs in Kigali, Rwanda, found that two thirds of calls were with friends and family rather than to customers or suppliers (Donner, 2005). While mobiles could be used to find new customers and expand business networks, they are just as likely to be used to amplify strong ties with existing personal relations (Donner, 2006).

In the DRC one of the basic revitalising factors for the country can be to support micro-firms so that they can employ work force and create new services. ICTs can be an important element for economic development and growth in the Congolese economy, which largely comprises microenterprises. The analysis of the effect on smaller enterprises is particularly important, because investment in these technologies can give them a competitive advantage and the ability to position themselves for better results (Pérez-Estébanez, Urquía-Grande and MuñozColomina, 2010) since they are more flexible and have greater responsiveness. Among the main problems encountered in micro-businesses, one is the lack of ICT, financial and accounting skills among the potential entrepreneurs. The important question of how to develop ICT and training in the DRC that fit into the local education system, cognitive competences and the economic and environmental policies is still unanswered. Educational centers in the DRC cannot assure business training that propels economic growth without the contribution of other factors, such as peace. Different cultures, like the ones that compose the current Congolese society, require different human qualities and social adjustments in order to reach wide-reaching development outcomes. Analysis of the social and other factors related to the different ICT tools can thus support new business projects. With the growing resource demands from industrialized countries, the DRC has become nothing more than a provider of raw materials to the rest of the world, structurally locked into a colonial trade pattern of exporting raw material and cash crops. Nevertheless, if supported by strategic policies and investments, this current level of industrialization, combined with ICT and the rich natural resource base, could open attractive opportunities for growth. Therefore, our research questions are:

RQ1: What factors determine the ICT level in micro-enterprises in the DRC?

RQ2: Is there a connection between revenues and asset measures and the ICT level in microenterprises in the DRC? 


\section{Data and Methods}

A survey was designed by the researchers and NPO directors to measure the ICT level and its impact on businesses and households in the DRC. Then the survey was tested by NPO directors. The survey uses a Likert scale from 1 to 5 (strongly disagree, disagree, neither agree or disagree, agree, and strongly disagree). The sample consisted of 200 stakeholders from a rural neighbourhood in Ngandanjike who were chosen randomly in the area of Mbujimayi in the south of the DRC where the NPO is working in several areas such as children's education, health, agriculture, communications, women empowerment and infrastructure. The NPO was created in 2006 and its director is a Congolese priest. Currently the NPO has installed the electricity of the rural hospital, is creating small micro-businesses for women (understanding these women are not from the agriculture sector and they are currently unemployed), manages an orphanage for children, has created a local radio and has built a church. Three of the NPO volunteers carried out the survey during the course of two months, explaining in French some of the questions about responsibility, networking or legitimacy to the respondents, concepts which turned out to be complicated for them.

The survey includes variables about their access to ICT, ICT training, ICT adoption level and ICT use. ICT adoption implies a process of evaluating strategically their possibility to plan within their micro-businesses and implement ICTs. ICT use refers to external and internal factors such as the use of mobiles, accounting information systems or e-commerce.

The majority of the respondents were women who answered that they are basically unemployed but they were still engaged in agricultural work on their own fields, which makes them agricultural micro entrepreneurs. $90 \%$ of them have a primary or secondary education and only a very small minority has any higher education background.

In Figure 1, a boxplot has been done to observe the total assets and total revenue averages. Total assets include for example land, housing and farm animals. Total revenue stems for example from the sales of agricultural products. The crops are produced largely for personal use so the total revenue of these agricultural micro-enterprises is very low and within total assets there were large differences. This suggests that there are huge differences in the income or wealth situation in the DRC. Further, there can be some outliers in the data, indicating difficulties among the respondents to understand the questions, either due to translation difficulties or because of the unfamiliarity of ICT concepts, especially to the poorest respondents.

\section{Figure 1}

The Cronbach's (1951) alpha (measuring the internal consistency of the data) was used to measure reliability. In our data, the Cronbach's alpha came out at 0,836 which indicates strong reliability according to George and Mallery (1995).

There are 19 variables in the study that were coded as shown in Table 2. The three first variables are the dependent variables: Level of ICT, Revenues and Assets. The rest of the variables are considered independent measures of the level of ICT of the agricultural microenterprises in the DRC. 
To study whether the economic and financial measures determine the ICT level in agricultural enterprises we took the total assets and total revenues of each micro-enterprise that was collected in the survey. Table 3 shows the correlation matrix to see the relationships between the variables.

Table 3

First, we can observe that the total revenue correlates with total assets. Secondly, revenue correlates with almost half of the ICT variables (in line with Dasuki et al., 2014 and Ojo et al., 2013). Additionally, total assets correlate with the majority of the ICT variables, in line with Heeks and Arun, 2010; Molla and Al-Jaghoub, 2007 and Esselaar et al. (2006).

In the next section we will analyzed which technological, economic and financial components influence the level of ICT in rural households and micro-enterprises using multivariate regression analysis (with the backward stepwise method).

\section{Results and discussion}

Two questions guided this study. First, what factors determine the ICT level in microenterprises in the DRC? Second, is there a connection between revenues and asset measures and the ICT level in micro-enterprises in the DRC?

Our findings regarding these two questions suggest that ICT development in the poorest areas of Africa is relatively slow and there is a lot of dispersion. Since the 1990s ICT research has studied the external and internal factors determining ICT use in developed countries. There aren't so many studies, however, that discuss the difficulties of measuring ICT development in the typical African context of agricultural micro-enterprises and that analyze the connections between the ICT level and the level of revenues or assets.

The "Coefficient B" column in Table 4 shows that the beta for Adequate level of training in ICT is positive $(0,127)$ and almost statistically significant $(p=0,074)$. The positive beta indicates that the ICT use of agricultural micro-enterprises is directly related to the level of training in ICT. In addition there is a positive relationship too between the level of ICT and the other components: Village ICT use level $(0,171)$, Use of mobiles for the management accounting in the micro-enterprise $(0,261)$ and use of ICT software for tax management $(0,347)$ and all of them are statistically significant. So in this case, the respondents see mobile phones and ICT as useful tools and consider ICT education necessary in line with Ewusi-Mensah (2012). 
When considering if there is a connection between the level of assets and the ICT level in agriculture micro-enterprises in the DRC, the results using a backward stepwise regression show that Country ICT use level, Use of e-commerce in the household, Enterprise access to ICT (mobile, internet, computer, broadband connection), Use of mobiles in micro-enterprise management, Use of mobiles for the management accounting in the micro-enterprise and Use of e-commerce in micro-enterprise remained significant in the final model regarding the level of total assets (Table 5).

Table 5

The analysis was also made for total revenues (Table 6), and several ICT use related coefficients were found statistically significant, including Access to electricity, Household ICT use level, Country ICT use level, Use of e-commerce in the household and Use of ICT software for the management accounting of micro-enterprise. In Table 5, the coefficient B column shows that all the coefficients are positive except for Country ICT use level and Use of ICT software for the management accounting of micro-enterprises in line with Loh (2013).

Table 6

We can observe that the access to ICT connects directly with Total Assets, in line with Bollou and Ngwenyama, 2008. It is interesting to observe that mobile phone use does relate to the Total Asset level in line with Donner, 2008 and Ojo, Janowski, and Awotwi, 2013. In fact Heeks (2010) and Ojo, Janowski and Awotwi (2013) affirm in their research that a mobile is a highly significant determinant for development. The results can be interpreted, however, in several ways and causality relations among the variables are not obvious. Further, a mobile phone can still be a major asset to the poorest in Africa and a sign of wealth and earlier good business instead of being a facilitator of new good business. Since technology and living standards are gradually improving in the poorest areas of Africa too, an interesting development project idea might be to distribute mobile phones and easy mobile services and training.

\section{Conclusions}

This research paper analyses technological, financial and economic factors determining the ICT level using a sample of 200 rural micro-enterprises in a large but poor area of the Democratic Republic of Congo (DRC). Our results suggest that ICT in micro-businesses can be a very important driver of economic development. The results indicate that ICT use of agricultural micro-enterprises is directly related to an adequate level of training in ICT and the use of mobiles or ICT software for business management (in line with Ewushi-Mensah, 2012 and Kayisire and Wei, 2016). Further, there is a connection between the level of ICT and the level 
of assets in line with Bollou and Ngwenyama (2008). Moreover, the use of mobile phone for business management is a clear feature, suggesting the importance of mobile phones for economic development. In our sample, micro-business total revenue was directly related to the level of ICT use.

Another important result is that the use of mobile phones in micro-business context relates to ICT (in line with Wade, 2004; Mbarika, 2002; Heeks and Arun, 2010 and Donner, 2006), suggesting the importance of mobile phones but also suggesting the strong intermingling of business and personal uses of the mobile among small business owners. This research adds empirical evidence to micro business level ICT, access and use as an engine of local economic growth in line with Oliveira and Fraga (2011). The results suggest that policy makers in developing areas may need to promote mobile phones, ICT training and microentrepreneurship to achieve economic development. Although additional research is still needed the progress in mobile technology might facilitate micro-entrepreneurs to find new business partners and customers via mobile applications and on-line market places for agricultural products.

This study fills a gap in the research into ICT usage by rural microbusinesses in developing countries by being the first to attempt to analyze rural microbusinesses in the DRC (as suggested by Loh, 2013). We could say that a limitation of this study is that the sample is small, so further research in this field is suggested. There can be translation problems in developing Africa with there being multiple tribes and languages, and especially if the researchers have to explain the survey to the translators who, at the same time, are attempting to explain the survey to the respondents. Potential misunderstandings might deserve further research, for example in understanding accounting and other business concepts in different contexts and under different traditions in Africa and globally. A practical measure in any future research would be to devote several sessions to informing and training both the interviewers and interviewees. 


\section{Bibliography}

Abraham, R. (2007). Mobile phones and economic development: evidence from the fishing industry in India. Information Technologies and International Development, 4(1), 5-17.

Anderson, D.R., Sweeney, D.J. and Williams, T.A. (2004). Estadística para Administración y Economía. Thomson, México.

Armenta, A., Serrano, A., Cabrera, M., and Conte, R. (2012) The new digital divide: the confluence of broadband penetration, sustainable development, technology adoption and community participation, Information Technology for Development, 18(4), 345-353

Bing, E. and Epstein, M. (2013) Pharmacy on a Bicycle. Innovative Solutions for Global Health and Poverty. Berret-Koehler Publishers inc.

Bollou,F., and Ngwenyama, O. (2008). Are ICT Investments Paying Off in Africa? An Analysis of Total Factor Productivity in Six West African Countries from 1995 to 2002. Information Technology for Development, 14 (4), 294-307

Brynjolfsson, E., and Hitt, L. (1998). Beyond the productivity paradox, Communications of the ACM, 41(8), 49-55.

Chowdhury, A. (2003). Information Technology and Productivity payoff in the banking industry:Evidence from the emerging markets. Journal of International Development, $15,693-708$.

Cooper, J. and Burgess, L. A model of Internet commerce adoption (MICA), in Rahman, S. M. and Raisinghani, M. S. (Eds.), Electronic commerce: Opportunity and Challenges, Idea Group, Hershey, PA. 2000:189-201.

Cronbach, L. (1951). Coefficient alpha and the internal structure of tests. Psychomerika, 16: 297-334.

Dasuki, S.I., Abbott, P. and Azerikatoa, D. (2014). ICT and empowerment to participate: a capability approach. Information and Development, 30 (4), 321-331.

Donner, J. (2008). Research approaches to mobile use in the developing world: A review of the literature. The Information Society, 24:140-159.

Donner, J., and Escobari, M.X. (2010). A review of evidence on mobile use my micro and small enterprises in developing countries. Journal of International Development 22, 641-658.

Dozier, K. and Chang, D. (2006). The effect of company size on the productivity impact of Information Technology Investments. Journal of Information Technology Theory and Application, 8(1), 33-47.

Esselaar, S., Stork, C. and Ndiwalana, A. (2006). ICT usage and its impact of profitability of SMEs in 13 African Countries. Berkley: International Conference on Information and Communication Technologies and Development, 40-47. 
Exenberger, A. and Hartmann, S. (2007). The Dark Side of Globalization. The Vicious Cycle of Exploitation from World Market Integration: Lesson from the Congo, Working Papers in Economics and Statistics 31, University of Innsbruck.

Ewushi - Mensah, K. (2012). Problems of information technology diffusion in sub-Saharan Africa: the case of Ghana, Information Technology for Development, 18 (3), 247-269.

George, D. \& Mallery, P. SPSS/PC+ Step by step. A simple guide and reference. Wadsworth Publishing, Belmont. 1995.

Ghaus-Pasha, A. (2007). Governance for the millennium development: Core issues and good practices. Building, 90.

Gujarati, D.N. 1995. Basic Econometrics, Literature Publication, Istanbul, p. 810.

Heeks, R. B. (2010). Development 2.0: the IT-enabled transformation of international development. Communications of the ACM, 53(4), 22-24.

Heeks,R. B., and Arun, S. (2010). Social outsourcing as a development tool. Journal of International Development, 22(4), 441-454.

Heeks, R. B., and Molla, A. (2009). Impact Assesment of ICT-for-Development projects: A compendium of approaches, Development Informatics Working Paper, 36, University of Manchester, UK.

Hilty, L., and Ruddy, T. (2010). Sustainable development and ICT interpreted in a natural science context. The resulting research questions for the social sciences. Information, Communication and Society, 13(1), 7-22.

Kabongo, J., \& Okpara, J. (2014). "ICT possession among Congolese SMEs: An exploratory study", Journal of Small Business and Enterprise Development, Vol. 21 No. 2, pp. 313326.

Karlan, D. and Appel, J. (2011). More than good intentions. How a new economics is helping to solve global poverty. Dutton, Penguin Books: England.

Karlan, D. and Valdivia, M. (2010). Impact of business training on microfinance clients and institutions. Review of Economics and Statistics.

Kayisire, D. and Wei, J. (2016). ICT Adoption and usage in Africa: towards an efficiency assessment. Information Technology for Development, 22 (4), 630-653.

Kivunike , F. N., Ekenberg, L., Danielson, M. and Tusubira, F. F. (2009). Investigating perception of the role of IT towards the quality of life of people in rural communities in Uganda. In Assessing the Contribution of ICT to Development Goals, E., Byrne B., Nicholson F. Salem (eds.), Dubai School of Government: UAE, 143-160.

Larsen, R.K., Powel, S., Sriskandarajah, N. and Peterson, T. (2010). Towards a learning model of ICT application for development. Lessons from a networked dialogue in Sweden. Information, Communication and Society, 13 (1), 136- 150. 
Levy, M. R., Chew, H.E., and llavarasan P. V. (2010). The economic impact of information and communication technologies (ICTS) on microenterprises in the context of development. Paper presented at International Communication Association Annual Conference, Singapore, 22-26 June.

Loh, Y.A.C. (2013). Approaches to ICT for development (ICT4D): vulnerabilities and capabilities. Information Development, 31 (3), 229-238.

Mansell, R. (2014). Power and interests in information and communication and development: Exogenous and Endogenous discourses in contention. Journal of International Development, 26, $109-127$.

Mason, D. R. (2014). Who gets what? Determinants of loan size and credit rationing among microcredit borrowers: Evidence from Nicaragua. Journal of International Development, 26, 77-90.

Maswera, T., Dawson, R. and Edwards, J. (2008). E-commerce adoption of travel and tourism organisations in South Africa, Kenya, Zimbabwe and Uganda, TelemaTIC and InformaTIC, 25(3): 187-200.

Mbaku, J. M. (2000). Governance, wealth creation and development in Africa: The challenges and the prospects. African Studies Quarterly, 4(2).

Mengiste, A. S., and Aanestad, M. (2013). Understanding the dynamics of learning across social worlds: A case study from implementing IS in Ethiopian public health care system. Information and Organization, 23, 233-257.

Molla, A., and Al-Jaghoub, S. (2007). Evaluating digital inclusion projects: a livelihood approach. International Journal of Knowledge and Learning, 3(6), 592-611.

Nunnally J and Bernstein L. Psychometric theory. New York: McGraw-Hill Higher, INC; 1994.

OECD Information Technology Outlook 2015. Available at http://www.oecd.org/sti/oecdinformatiotechnologyoutlook

Ojo, A., Janowski, T., and Awotwi, J. (2013). Enabling development through governance and mobile technology. Government Information Quaterly, 30, 32-45.

Olatokun, W. M. (2009). Analysing socio-demographic differences in access and use of ICTs in Nigeria using the capability approach. Issues in Informing Science and Information Technology, 6, 479-496.

Oliveira, T. and Fraga Martins, M. (2011). Literature Review of Information Technology adoption models at firm level. The Electronic Journal of Information Systems Evaluation, 14 (1), 110-121. 
Orlikowski, W. J., and lacono, C. S. (2001). Research commentary: Desperately seeking the "IT" in IT research - A call to theorizing the IT artifact. Information Systems, 12 (2), 121134.

Pade-Khene, C., Mallinson, B. and Sewry, D. (2011). Sustainable rural ICT project management practice for developing countries: investigating the Dwesa and RUMEP projects. Information Technology for Development Vol. 17 (3), 187-212

Pade-Khene, C., Mallinson, B., and Sewry, D. (2008a). An elaboration of critical success factors for rural ICT project sustainability in developing countries: Exploring the Dwesa case. The Journal of Information Technology Case and Application, 10 (4), 32-55.

Pérez Estébanez, R., Urquía Grande, E. and Muñoz Colomina, C. (2010). Information Technology implementation for continuous improvement: Empirical evidence in Spanish SME's. International Journal of Accounting and Information Management, 18 (1), 39-57. Outstanding Paper Award 2011.

Pick, J.B., Gollakota, K. and Singh,M. (2014). Technology for Development: Understanding Influences on use of Rural Telecenters in India. Information Technology for Development, 20 (4), 296-323.

Quereshi, S. (2006). Collaboration for knowledge networking in development. Information Technology for Development, 12(2), 87-89.

Rogers, E. M. (2003). Diffusion of innovations (5th ed.). New York: Free Press.

Sein, M. K. (2004). Conceptualizing the ICT artifact: Towards understanding the role of ICT in national development. The Information Society, 20, 15-24.

Solow, R. (1957). A contribution to the theory of economic growth. Quarterly Journal of Economics, 70, 65-94.

Tongia, R., Subrahmanian, E. and Arunachalam, V. S. (2004). Information and communications technology for sustainable development defining a global research agenda (1-129).

Walsham, G., and Schay, S. (2006). Research on Information Systems in Developing Countries: Current Landscape and Future Prospects. Information Technology for Development, 12(1), 7-24

Wooldridge, J.M. (2013). Introductory Econometrics: A Modern Approach. Fifth Edition. SouthWestern Cengage Learning. USA. ISBN-13: 978-1111531041.

http://www.worldbank.org/ 
Figure 1: Boxplot of total revenues and total assets

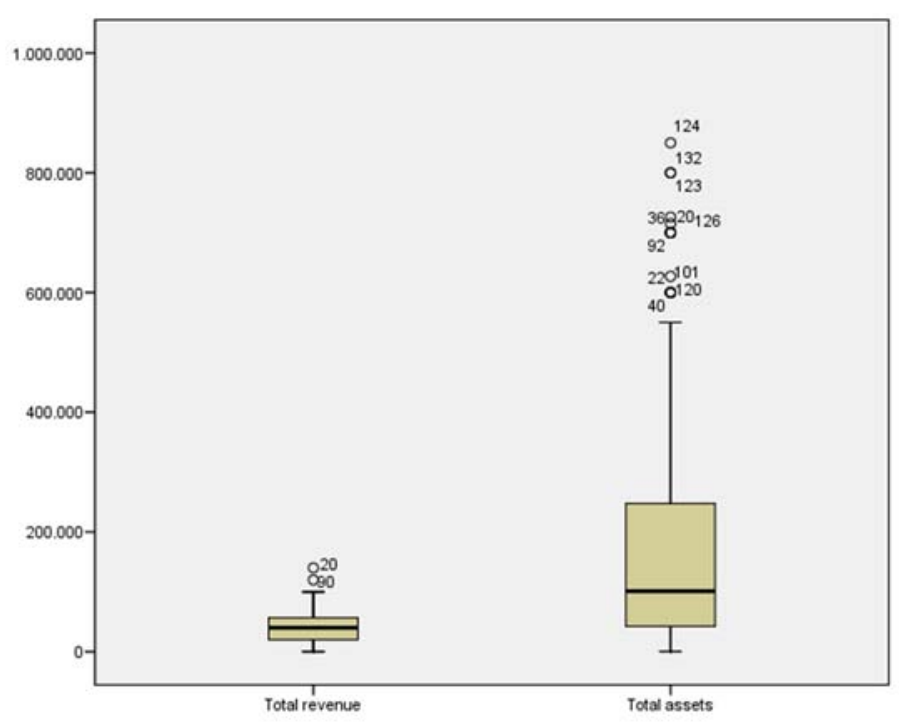


Tabla 1. Economic, technology and development data

\begin{tabular}{|c|c|c|c|}
\hline \multicolumn{2}{|l|}{ Concept } & Year & Output \\
\hline \multirow{2}{*}{ Electric power } & Consumption per capita & 2013 & $110 \mathrm{kws}$ \\
\hline & $\begin{array}{l}\text { Transmission and } \\
\text { distribution losses }\end{array}$ & 2013 & $7 \%$ of output \\
\hline \multirow{4}{*}{ Telephones access and use } & Fixed telephone & 2015 & $\begin{array}{l}0 \text { Subscriptions per } \\
100 \text { people }\end{array}$ \\
\hline & Mobile cellular & 2015 & $\begin{array}{l}53 \text { Subscriptions per } \\
100 \text { people }\end{array}$ \\
\hline & Fixed telephone & 2014 & $\begin{array}{c}0 \text { International voice } \\
\text { traffic minutes per } \\
\text { person }\end{array}$ \\
\hline & Mobile cellular network & 2014 & $\begin{array}{c}13 \text { International } \\
\text { voice traffic minutes } \\
\text { per person }\end{array}$ \\
\hline Telephones quality & $\begin{array}{l}\text { Population covered by } \\
\text { mobile cellular network }\end{array}$ & 2015 & \\
\hline & & & $50 \%$ \\
\hline \multirow{4}{*}{$\begin{array}{c}\text { Telephones affordability and } \\
\text { efficiency }\end{array}$} & $\begin{array}{l}\text { Fixed telephone sub- } \\
\text { basket }\end{array}$ & 2013 & $9.9 \$$ per month \\
\hline & $\begin{array}{l}\text { Mobile cellular sub- } \\
\text { basket }\end{array}$ & 2013 & $11.9 \$$ per month \\
\hline & Telecom revenue & 2014 & $3.0 \%$ of GDP \\
\hline & $\begin{array}{c}\text { Mobile cellular and fixed } \\
\text {-line subscribers per } \\
\text { employee }\end{array}$ & 2014 & 14,841 \\
\hline Population & & 2015 & 77.27 million \\
\hline GDP & & 2015 & $\$ 35.24$ billion \\
\hline GDP growth & & 2015 & $6.9 \%$ \\
\hline Inflation & & 2014 & $1.6 \%$ \\
\hline HDI index & & 2014 & 0.433 \\
\hline
\end{tabular}


Table 2: Codification of variables

\begin{tabular}{|c|c|}
\hline Variable & Code \\
\hline ICT_TOTAL & $\mathrm{ICT}$ \\
\hline Total_revenue & REV \\
\hline Total_assets & ASS \\
\hline Access to electricity & A_E \\
\hline Adequate level of training in ICT & $L_{-} T$ \\
\hline Household ICT use level & H_L \\
\hline Village ICT use level & V_L \\
\hline Country ICT use level & C_L \\
\hline Enterprise access to ICT (mobile, internet, computer, broadband connection) & E_A \\
\hline Training in using mobiles for the business & T_Mo \\
\hline Use of e-commerce in household & E_H \\
\hline Use of ICT in the micro-enterprise & U_M \\
\hline Use of ICT for tax management & T_M \\
\hline Use of ICT for business management & B_M \\
\hline Use of mobiles in micro-enterprise management & M_M \\
\hline Use of mobiles for the management accounting in the micro-enterprise & M_A \\
\hline Use of e-commerce in micro-enterprise & E_E \\
\hline Use of ICT software for the management accounting of micro-enterprise & S_A \\
\hline Use of ICT software for tax management & S_TM \\
\hline
\end{tabular}




\section{Table 3: Correlation Matrix}

\begin{tabular}{|c|c|c|c|c|c|c|c|c|c|c|c|c|c|c|c|c|c|c|c|}
\hline & ICT & REV & ASS & A_E & $L_{-} T$ & H_L & V_L & C_L & E_A & T_M & $E_{-} H$ & U_M & T_M & B_M & M_M & M_A & E_E & S_A & S_TM \\
\hline \multicolumn{20}{|l|}{ ICT } \\
\hline REV & $-0,165^{*}$ & & & & & & & & & & & & & & & & & & \\
\hline ASS & $-0,034$ & $0,375^{* *}$ & & & & & & & & & & & & & & & & & \\
\hline A_E & 0,072 & $0,154^{*}$ & 0,086 & & & & & & & & & & & & & & & & \\
\hline$L_{-} T$ & $0,116^{*}$ & $0,151^{*}$ & $0,120 *$ & $0,188^{* *}$ & & & & & & & & & & & & & & & \\
\hline H_L & $0,119 *$ & 0,048 & $0,204 * *$ & $-0,094$ & $0,209 * *$ & & & & & & & & & & & & & & \\
\hline V_L & $0,142 *$ & $-0,025$ & $0,182^{* *}$ & $0,109 *$ & $0,135^{*}$ & $0,660 * *$ & & & & & & & & & & & & & \\
\hline C_L & $0,200 * *$ & $-0,076$ & $0,236^{* *}$ & 0,013 & 0,067 & $0,521 * *$ & $0,686^{* *}$ & & & & & & & & & & & & \\
\hline E_A & 0,049 & $0,142 *$ & $0,216 * *$ & $0,363^{* *}$ & $0,267^{* *}$ & $-0,12$ & 0,056 & 0,034 & & & & & & & & & & & \\
\hline T_Mo & $0,153^{*}$ & 0,008 & $0,126^{*}$ & $-0,08$ & $0,467 * *$ & 0,01 & $-0,066$ & $0,147^{*}$ & $0,294 * *$ & & & & & & & & & & \\
\hline E_H & $-0,08$ & $0,225^{* *}$ & $0,279 * *$ & $-0,03$ & $0,292 * *$ & 0,059 & 0,032 & $-0,02$ & $0,442 * *$ & $0,27 * *$ & & & & & & & & & \\
\hline U_M & $-0,033$ & 0,022 & $0,112^{*}$ & $-0,03$ & 0,092 & $-0,055$ & 0,032 & 0,011 & $0,203 * *$ & $0,12 *$ & $0,494 * *$ & & & & & & & & \\
\hline T_M & 0,049 & $0,101^{*}$ & $-0,04$ & $-0,038$ & $0,181^{* *}$ & 0,002 & 0,078 & 0,066 & $0,105^{*}$ & 0,01 & $0,146^{*}$ & $0,146^{*}$ & & & & & & & \\
\hline B_M & $-0,057$ & $0,104 *$ & $0,197 * *$ & $-0,021$ & $0,159 *$ & 0,015 & $-0,005$ & $-0,04$ & $0,312 * *$ & $0,19 * *$ & $0,705^{* *}$ & $0,705^{* *}$ & $0,216 * *$ & & & & & & \\
\hline M_M & 0,096 & 0,02 & 0,048 & $0,255^{* *}$ & $-0,008$ & $-0,124 *$ & $-0,16^{*}$ & 0,067 & 0,092 & $0,39 * *$ & $0,128 *$ & $0,128 *$ & 0,029 & $0,189 * *$ & & & & & \\
\hline M_A & $0,109 *$ & ,000 & 0,009 & $0,264 * *$ & $-0,04$ & $-0,13^{*}$ & $-0,162 *$ & 0,076 & 0,031 & $0,35^{* *}$ & $-0,01$ & $-0,01$ & $-0,01$ & $-0,01$ & $0,98 * *$ & & & & \\
\hline E_E & $-0,072$ & 0,002 & $0,177 * *$ & $-0,027$ & $0,291 * *$ & 0,069 & 0,046 & $-0,01$ & 0,074 & $0,04 * *$ & $0,216^{* *}$ & 0,216 & $0,059 * *$ & 0,311 & 0,052 & 0,01 & & & \\
\hline S_A & $-0,099 *$ & $-0,015$ & $0,115^{*}$ & 0,034 & $0,277^{* *}$ & 0,056 & 0,088 & $-0,07$ & $0,151^{*}$ & 0,09 & $0,4^{* *}$ & $0,4 * *$ & $0,114^{*}$ & $0,574 * *$ & $0,1^{*}$ & 0,01 & $0,17^{* *}$ & & \\
\hline S_TM & $0,126^{*}$ & 0,091 & $-0,063$ & $-0,029$ & $-0,04$ & 0,095 & 0,07 & 0,075 & $-0,04$ & $-0,03$ & $-0,01$ & $-0,01$ & $-0,01$ & $-0,01$ & $-0,01$ & 0,01 & $-0,01$ & 0,01 & \\
\hline
\end{tabular}

** Correlation is significant at the 0.01 level (2-tailed). 
Table 4. Technological factors that determine the ICT level in agriculture micro-enterprises in developing countries

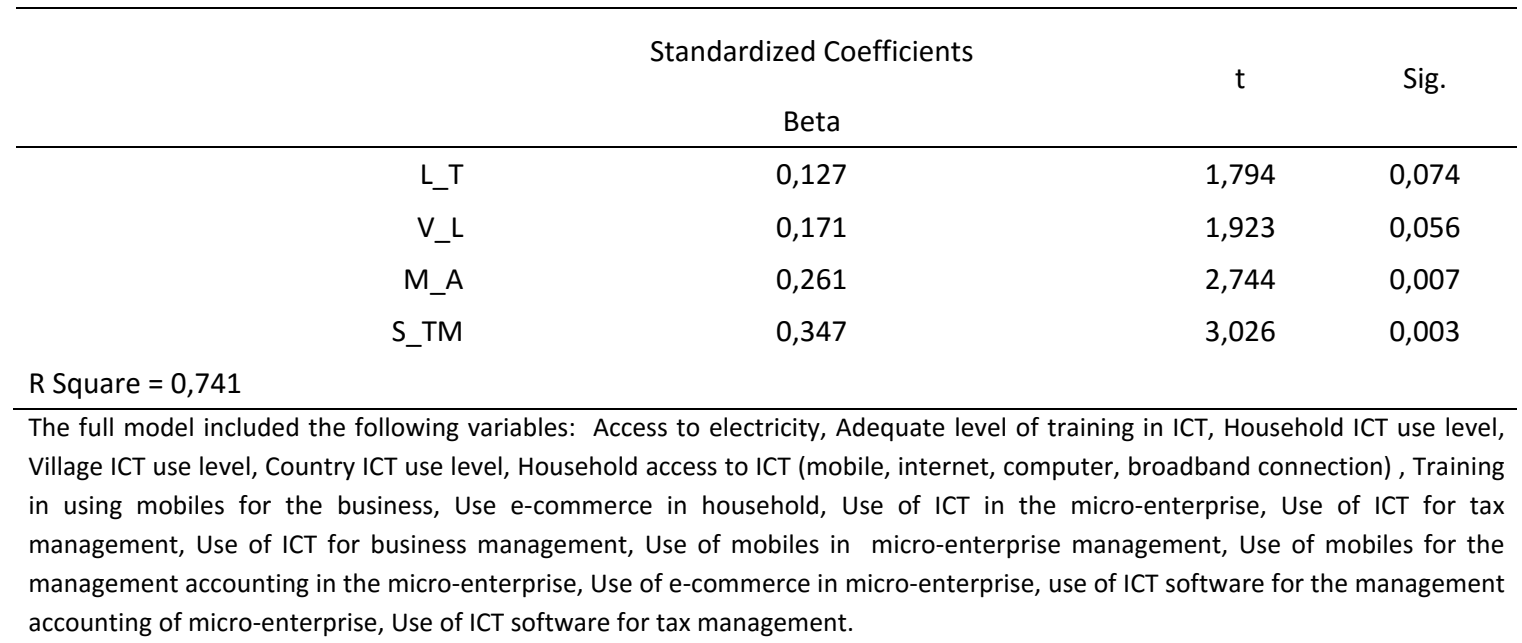

Dependent Variable: TOTAL_ICT

Table 5. Connection between economic wealth and ICT (Total_Assets)

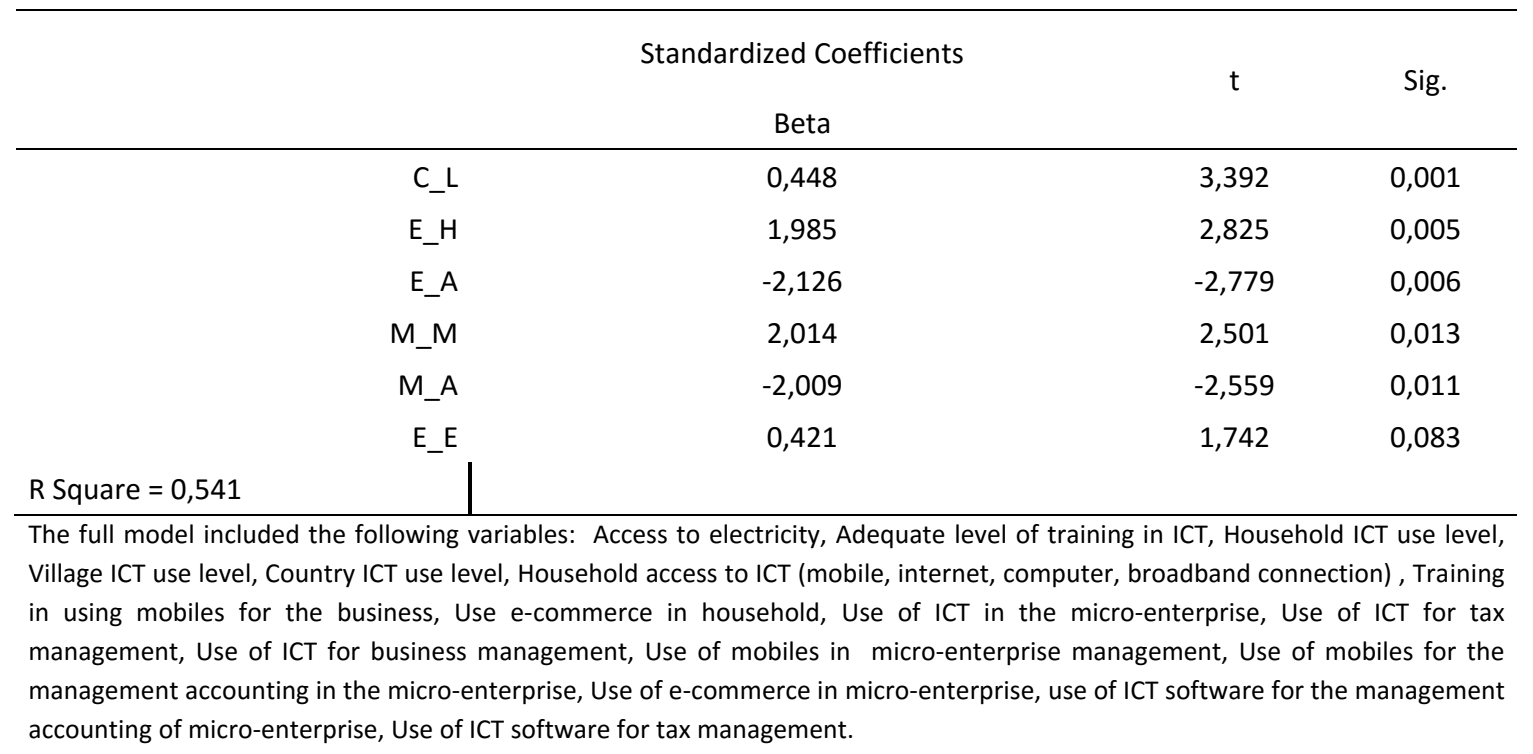

Dependent Variable: TOTAL_ASSETS

Table 6. Connection between economic wealth and ICT (Total_Revenues)

\begin{tabular}{cccc}
\hline & Standardized Coefficients & S & Sig. \\
\hline A_E & Beta & 2,564 & 0,011 \\
H_L & 0,214 & 1,666 & 0,097 \\
C_L & 0,169 & $-1,947$ & 0,053
\end{tabular}




$\begin{array}{lccc}\text { E_H } & 1,41 & 4,411 & 0,000 \\ \text { S_A } & -0,706 & -2,243 & 0,026\end{array}$

R Square $=0,733$

The full model included the following variables: Access to electricity, Adequate level of training in ICT, Household ICT use level, Village ICT use level, Country ICT use level, Household access to ICT (mobile, internet, computer, broadband connection), Training in using mobiles for the business, Use e-commerce in household, Use of ICT in the micro-enterprise, Use of ICT for tax management, Use of ICT for business management, Use of mobiles in micro-enterprise management, Use of mobiles for the management accounting in the micro-enterprise, Use of e-commerce in micro-enterprise, use of ICT software for the management accounting of micro-enterprise, Use of ICT software for tax management.

Dependent Variable: TOTAL_REVENUES 